\title{
DISORIENTING FICTIONS: ANTJE RÁVIC STRUBEL AND POST-UNIFICATION EAST GERMAN IDENTITY
}

\author{
EMILY JEREMIAH
}

\begin{abstract}
This article explores the work of Antje Rávic Strubel (b. 1974), setting it in the context of recent debates concerning post-unification East German identity. Drawing on the work of Rosi Braidotti and Sara Ahmed, it defines Strubel's work as 'nomadic' and 'queer', and explores the novel Offene Blende (2001) in this light. It goes on to examine two male characters in later works by Strubel, Kältere Schichten der Luft and Vom Dorf (both 2007), before briefly investigating Strubel's 2008 guidebook to Sweden. Avoiding both 'Ostalgie' and self-effacement, Strubel's work explores the 'homelessness' of the East German in today's Berlin Republic - in particular, that of the older, East German man - but it also suggests the liberating possibilities of this condition, in a manner reminiscent of Braidotti. In addition, Strubel offers a dual challenge to nationalism and heterosexism, paving the way for new understandings of Germanness.
\end{abstract}

East German identity following the 'Wende' remains precarious and problematic. The 'imagined community' of Germany - to allude to Benedict Anderson's 1983 discussion of the nation - is divided and tense. ${ }^{1}$ The integration of former GDR citizens into this 'community' has been 'a fractious, often confrontational process that is far from complete'. ${ }^{2}$ The celebratory sense of unity felt by many East Germans around the time of reunification, with protestors famously proclaiming 'Wir sind ein Volk', soon gave way to resentment and alienation, as the 'Mauer im Kopf' held firm. ${ }^{3}$ In 1991, the psychiatrist Hans-Joachim Maaz claimed that the 'Wende' had led many East Germans to 'Resignation, Depressivität, Larmoyanz, Gereiztheit und Gewalt'. ${ }^{4}$

Such despondency has prompted numerous reactions in the cultural sphere. The phenomenon of 'Ostalgie', whereby the GDR is viewed in a nostalgic, indulgent light, can be viewed as one such (unhelpful) response. ${ }^{5}$ But as Paul Cooke notes, one should be wary of taking a simplistic view of the issue, since nostalgia is perhaps an inevitable element of

\footnotetext{
${ }^{1}$ Benedict Anderson, Imagined Communities: Reflections on the Origin and Spread of Nationalism, London 1983, pp. 14-15.

${ }^{2}$ Dolores L. Augustine, 'The Impact of Two Reunification-Era Debates on the East German Sense of Identity', German Studies Review, 27 (2004), 563-78 (563).

${ }^{3}$ Ibid., 572. See also Hans-Joachim Maaz, Das gestürzte Volk. Die unglückliche Einheit, Berlin 1991, p. 154.

${ }^{4}$ Maaz, p. 33.

${ }^{5}$ For examples of uses of this term, see Frank Thomas Grub, 'Wende' und 'Einheit' im Spiegel der deutschsprachigen Literatur, Band 1: Untersuchungen, Berlin 2003, pp. 558-62.
} 
nation-building. Addressing the questions of memory and identity, Cooke also observes that 'one's past should neither be denied, nor unproblematically evoked', for it serves as 'a necessary co-ordinate' in the process of identity-construction. ${ }^{6}$

The work of Antje Rávic Strubel (b. 1974) complements and enriches such discussions, as we will see. Strubel's work, which I view as 'nomadic' and 'queer', both asserts and destabilises an East German identity, undermining attempts to frame, commemorate, or perpetuate such an identity in any 'unproblematic' way. Strubel depicts the troubled homelessness of the East German subject, but she also suggests the liberating potential of this condition, in a manner reminiscent of postmodernist theorists such as Rosi Braidotti. I will firstly explain what I mean by 'nomadic' and by 'queer', before introducing Strubel and her work.

\section{NOMADIC DISORIENTATIONS}

In her 1994 Nomadic Subjects, Braidotti critiques traditional philosophical understandings of identity as unified and stable, and puts forward "nomadism' as an alternative figuration. ${ }^{7}$ Polyglottal and transnational, the nomadic subject is joyfully open and mobile. ${ }^{8}$ In the context of German Studies, 'nomadism' provides a useful way of going beyond ideas of Germanness as fixed and homogenous; in this way, it ties in with numerous discussions in contemporary German Studies. ${ }^{9}$ Such debates acknowledge (German) identity as constructed and shifting - this in the context of a globalised world, in which increased ease of travel and advances in communication, especially the internet, mean that national borders are arguably more fluid than before. As Stephen Brockmann observes: 'With the advent of globalization and international dependency, it is probably national insecurity $[\ldots]$ that is the rule [in Germany]. ${ }^{10}$

This is not to abandon 'Germanness', or 'nation', as categories; as Brockmann notes, the nation continues to play an important role in contemporary life. ${ }^{11}$ Rather, it is to focus on the ways in which these categories are open to revision. For the East German subject, this potential for change is all too clear. The East German Maaz writes of his own experience of the 'Wende': 'Ich wollte immer hinausströmen und durfte nicht, jetzt werde ich zur Expansion verführt und verliere mich dabei. ${ }^{12}$ East German

\footnotetext{
${ }^{6}$ Paul Cooke, 'Performing “Ostalgie”: Leander Haussmann's Sonnenallee', GLL, 56 (2003), 156-67 (167).

${ }^{7}$ Rosi Braidotti, Nomadic Subjects: Embodiment and Sexual Difference in Contemporary Feminist Theory, New York 1994. A 'figuration' is 'a politically informed account of an alternative subjectivity' (p. 1).

${ }^{8}$ Ibid., p. 8.

${ }^{9}$ See here Stephen Brockmann, Literature and German Reunification, Cambridge 1999, p. 17.

${ }^{10}$ Ibid., p. 192.

${ }^{11}$ Ibid., p. 18.

12 Maaz, p. 19.
} 
'nomadism' can be difficult, then - and as we will see, Strubel's work suggests both the dangers and the pleasures of mobility.

It also depicts queer experience, highlighting same-sex desire and implying possible new understandings of gender and kinship, in a manner reminiscent of the critical theorist Sara Ahmed. Ahmed investigates the political and ethical potential of not following straight lines and set paths; of not, for example, reproducing and so perpetuating the family 'line'. She suggests that these queer divergences might be illuminating: 'to live out a politics of disorientation might be to sustain wonder about the very forms of social gathering ${ }^{13}{ }^{13}$ Queer theory does not take for granted the necessity or desirability of the institution of the heterosexual, nuclear family, and is in general concerned to scrutinise dominant understandings of gender.

If 'nation' and 'gender' are intertwined institutions, as has been claimed, then challenging gender also involves challenging nation, and 'nomadism' and 'queerness' are complementary conditions or viewpoints. ${ }^{14}$ And if Strubel is right in her assertion that the German state in particular relies on the institution of the (bourgeois, heterosexual) family, then a queer take on Germany might be especially productive. ${ }^{15}$ As far as East German identity is concerned, it is interesting to observe that the relationship between East and West Germany has more than once been described as a difficult marriage, in which East Germany occupies the feminised position of 'wife' ${ }^{16}$ If the binaries implied by this analogy (man/woman, active/passive etc.) are deconstructed, then the way is clear for more helpful and nuanced formulations of East and West German identities. Queer theory, which often stresses the 'performative' aspect of gender, could assist in this undertaking. ${ }^{17}$

To turn to Strubel: Antje Strubel ${ }^{18}$ was born in Potsdam in 1974, and grew up in Ludwigsfelde in the GDR. After leaving school in 1992, she trained to be a bookseller. From 1994, she studied American Studies, Psychology, and Literature at Potsdam University and at New York University. She worked as a lighting technician at Wings Theater in New York. She gained her Master's degree in 2001, and is now based in Potsdam, spending a significant part of every year in Sweden. Offene Blende, her first novel, was published

\footnotetext{
${ }^{13}$ Sara Ahmed, Queer Phenomenology: Orientations, Objects, Others, Durham, NC 2006, p. 24.

${ }^{14}$ See here Nira Yuval-Davies, Gender and Nation, London 1997, pp. 4 and 7.

${ }^{15}$ Strubel makes this claim in Gebrauchsanweisung für Schweden, Munich 2008, p. 191.

${ }^{16}$ Anke Pinkert, "Postcolonial Legacies”: The Rhetoric of Race in the East/West German National Identity Debate of the Late 1990s', The Journal of the Midwest Modern Language Association, 35 (2002), 13-32 (13).

${ }^{17}$ See here Judith Butler, Gender Trouble: Feminism and the Subversion of Identity, New York 1990, p. 33.

${ }^{18}$ According to her website Strubel adopted the name 'Rávic' when her first book was published: 'Mit Erscheinen des Buches [Offene Blende] entschied sie sich für einen Autorinnamen; sie ergänzte ihren bürgerlichen Namen um den Namen Rávic, der eine Erfindung ist. Er bezeichnet eine weitere Identität, die ihrer Person während des Schreibens zukommt' (<www.antjestrubel.de> (accessed 23 April 2007)).
} 
in 2001 and was well received. ${ }^{19}$ It was followed by five further novels and a guidebook to Sweden. Strubel has also translated into German Joan Didion's memoir The Year of Magical Thinking. ${ }^{20}$

I will discuss, firstly, Offene Blende, arguing for a queer, nomadic view of this text and showing how it frames East Germanness in ways that are neither nostalgic nor reductive. I will then examine two male East German characters in the later works Kältere Schichten der Luft and Vom Dorf (both published in 2007); these disturbed figures suggest the difficulties faced by East German men in particular in today's Berlin Republic. I will touch, finally, on Strubel's book about Sweden. We will see throughout that Strubel's queer nomadism fuels a fruitful challenge both to heterosexism and to nationalism, and that her work offers a powerful contribution to debates about contemporary German identity.

\section{OFFENE BLENDE: QUEER NOMADISM}

Strubel's first novel tells the story of Christiane, who leaves the GDR for the United States in the 1980s. Calling herself 'Jo', she establishes a theatre company in New York. In the mid-1990s, ${ }^{21}$ she encounters Leah, a young photographer originally from Marburg. Leah has moved to New York from Berlin and is seeking employment. The two women form a relationship. At the end of the work Christiane claims that she wants to return to Germany, and leaves.

In the character of Christiane, an East German, queer subjectivity is foregrounded. The work thus arguably deals with two forms of 'otherness'. It depicts East German identity as precarious and submerged. We learn that prior to leaving the GDR, Christiane applied to marry an American man. She was consequently declared 'staatenlos', following which: 'Sie faltete sich Straße für Straße wie einen Stadtplan immer kleiner zusammen, bis sie in ihre Hosentasche paßte' ( $O B$, p. 268). Christiane quashes and conceals her (national) identity. She passes herself off as American, and lives under an assumed name. However, she cannot deny her origins; 'being American' is harder than she assumes $(O B$, p. 53), and Cooke's observation regarding the connection between memory and identity is borne out. Following her encounter with Leah, memories of her life in the GDR come back to Christiane: 'Sie kommen wieder, die Bilder der Kindheit. Sie sind nicht verschollen, vergessen, eingegangen [...] in Ortsveränderungen und

\footnotetext{
${ }^{19}$ Franziska Meyer, “"und dabei heißt es immer aufbruchsstimmung”. Das Verschwinden einer Metropole in ihren Texten', in Pushing at Boundaries: Approaches to Contemporary Women Writers from Karen Duve to Jenny Erpenbeck, ed. Heike Bartel and Elizabeth Boa, Amsterdam 2006, pp. 167-84 (p. 168).

${ }^{20}$ For a list of works and further information, see $<$ www.antjestrubel.de $>$.

21 'Das Ende der DDR liegt nun schon mehr als sechs Jahre zurück'. Antje Rávic Strubel, Offene Blende, Munich 2001, p. 276. Further references to the novel appear as $O B$.
} 
fremdsprachige Floskeln' ( $O B$, p. 242). Christiane's failure to repress such images recalls Judith Butler's assertion that: 'None of us can fully answer to the demand to "get over yourself!"'22 (East German) identity is not to be transcended. In this way, Strubel's text affirms the specificity of the East German experience, even as it shows it to be opaque and difficult to access.

The GDR is not romanticised here; this is not an 'ostalgic' text. Christiane's decision to flee East Germany is an obvious gesture of rejection of that state. Christiane recalls her life in the GDR in two extended flashbacks (OB, pp. 245-53, 259-69). We learn, for example, that '[d] as Theater gehörte zu den wenigen verwunschenen Plätzen, an denen man nicht alles, was man sagen wollte, erst durch ein Geheimnis hindurchschicken mußte' $(O B$, p. 261). The repressiveness of the regime is thus underscored. Christiane has a relationship with a female factory worker, who flees to the West $(O B$, p. 267) - again, flight is highlighted, as it is in Strubel's later novel Tupolew 134, a fictionalised account of the real-life hi-jacking of an aeroplane by two East Germans intending to commit 'Republikflucht'. ${ }^{23}$ Thus, Strubel emphasises the political construction of space and the consequences for individual agency; as Ahmed notes 'doing things' depends upon 'the ways in which the world is available as a space for action'. ${ }^{24}$ The child Christiane has 'blinde[] Stellen in ihrem Kopf' which correspond to the divided-off part of Berlin (OB, p. 8).

Like Maaz, however, Strubel does not unequivocally celebrate the 'Wende' and the new freedoms it apparently offered to East Germans. It is, rather, viewed critically. Christiane asks Leah about the fall of the Wall, terming it a 'Spektakel' ( $O B$, p. 112). Leah herself describes the crowds present as '[e]in Getümmel von Halbirren', remembering the atmosphere as 'falsch und übertrieben' and viewing the event as 'ein amerikanisches Ereignis' in its spectacular quality ( $O B$, pp. 112, 114). Elsewhere, Christiane leaves untouched a newspaper that proclaims 'das Ende vom Ostblock und den Sieg der demokratischen Kräfte' $(O B$, p. 140). The work thus implies ambivalence about the 'Wende' and the celebratory discourses surrounding it. It also implies criticism of post-unification Germany; the Berlin that Leah has left behind has become tweely gentrified; 'Designer und Architekten aus Erlangen und Bochum' have moved in $(O B$, p. 94$) .{ }^{25}$

Contemporary German identity is in general vexed. For Leah, too, the question of being 'from' somewhere is not simple; it is a question she problematises when it is first posed to her by Christiane ( $O B$, pp. 85-6). Despite Leah telling Christiane and the latter's friend Harvey that she is from Marburg, the pair insist that she is from Berlin, prompting the reflection:

\footnotetext{
${ }^{22}$ Judith Butler, Bodies that Matter, New York 1993, p. 117.

${ }^{23}$ Antje Rávic Strubel, Tupolew 134, Munich 2004.

${ }^{24}$ Ahmed, p. 109.

${ }^{25}$ Compare Strubel, Gebrauchsanweisung, in which contemporary Berlin is described as 'zerfasert[] und zusammengestoppelt[]' (p. 142).
}

(C) The author 2009. Journal compilation (C) Blackwell Publishing Ltd. 2009 
'[Leah] existierte nur als Begriff, als Vorstellung von einem europäischen Staat mit unangenehmer Vergangenheit' $(O B$, pp. 116-17, 118). National identity is, then, a construct, a set of ideas and associations. It is filtered through perceptions and prejudices. (West) Germans are viewed as hardworking, for example ( $O B$, p. 109). East Germany is ignored or 'othered' by Americans $(O B$, p. 20). On learning Christiane's country of origin, one American character concludes: 'So you are a communist' $(O B$, p. 52; see also $O B$, p. 75). Conversely, in Christiane's eyes New York corresponds to representations of America in the GDR intended to shock (OB, p. 19). In addition, ideas of sameness and difference are complicated, in a challenge to discrete nationalities and homelands. For Leah, America is 'viel zu vertraut'; Central Park resembles the 'Tiergarten' $(O B$, p. 83; see also $O B$, p. 153).

While nation and nationality are deconstructed, their importance is nonetheless affirmed. The nation still matters, as Brockmann observes. When Christiane generalises about Germans and Leah protests, the former teases the latter, calling her 'meine kleine Individualistin':

'...wer fühlt sich schon so wie sein Land!'

'Viele. Wegen der ganzen Kultur und Tradition und so,' sagte Leah schwach. 'Ach was. Man wird geboren und aufgezogen und stirbt, egal, wo man sein Leben zubringt. Sonst wäre das doch schrecklich. Man wäre regelrecht eingepflanzt. Man wäre nichts als sein Land'. ( $O B$, p. 206)

For Christiane, the nationalist narrative is too restrictive, then; a view which suits her, since she has attempted to repress her past. At the same time, however, she challenges the view that one can simply be an 'individual', free of any external influence; and as suggested, she herself cannot escape her origins. Elsewhere, Leah experiences 'das hartnäckige Heimatgefühl' $(O B$, p. 143). The concept of 'Heimat' is itself, of course, uniquely German. ${ }^{26}$ Christiane, too, expresses the wish to return to Berlin, which Leah evokes for her by means of description $(O B$, p. 307). However, it is not clear whether Christiane does in fact return to Germany (OB, p. 311). Christiane's (probable) failure to return to Germany thus problematises the ideal of 'Heimat', and disrupts the traditional 'Heimat' narrative, which often ends with a return or a reconciliation. ${ }^{27}$ It also suggests the difficulty for East Germans of being part of the Berlin Republic.

The East German subject in this novel is a complex construct. The frequent references to disguise and performance in the text challenge understandings of identity as fixed and static. Christiane dresses up for Leah:

\footnotetext{
${ }^{26}$ See here Elizabeth Boa and Rachel Palfreyman, Heimat - A German Dream: Regional Loyalties and National Identity in German Culture 1890-1990, Oxford 2000. The authors discuss the untranslatable nature of the term 'Heimat' (p. 1).

${ }^{27}$ See Boa and Palfreyman, Heimat, pp. 25-9.
} 
“"Das hier ist eine andere Person. Und die habe ich jetzt für dich eingekleidet"' $(O B$, p. 196). Such a performative understanding of identity is key to many queer theories, as mentioned; and this is a queer text, most obviously in its depiction of lesbian experience. Christiane leaves the GDR ostensibly to marry an American man, whom she then avoids (see $O B$, p. 17). Similarly, in Tupolew 134, the protagonist uses a man as an escape route out of the GDR; in fact, she is attracted to her female friend..$^{28}$ Other orientations are thereby pointed up and affirmed, as 'desire lines' are followed. ${ }^{29}$ Strubel also queers space. It is suggested that lesbian intimacy is not sanctioned in public spaces, while heterosexual acts are permitted (OB, pp. 204, 267); this goes both for the GDR and the US. Placelessness is indeed a problem for Christiane. Her location is uncertain at the close of the novel, as is the future of her relationship with Leah, which is in general characterised by tension and ambivalence. But while the novel exposes the difficulty involved in being marginal - foreign and/or queer - it itself offers a challenge to that marginalisation. As Ahmed observes in connection with queerness: 'The unhappiness of the deviant performs its own claim for justice. ${ }^{30}$

In Offene Blende, then, (East German) identity is elusive and fraught with problems. The subject here is changeful and ungraspable; Strubel's work insistently highlights and problematises the issues of representation and communication. Leah attempts to capture Christiane by means of her photographs, but the resulting image is too small: 'Sie wollte alles klar und deutlich und viel größer haben' ( $O B$, p. 121; see also $O B$, pp. 210-11, 213). The text thus implicitly casts doubt on its own ability to capture and convey 'East German identity'. It does, however, affirm East Germanness as a distinct set of memories and experiences, as we have seen; these are difficult, even traumatic, and subject to repression. Such difficulty is pointed up elsewhere in Strubel's work, as we will now see.

\section{THE ‘WENDE’ AND EAST GERMAN MASCULINITY}

In Offene Blende and the briefly discussed Tupolew 134, Strubel shows us queer, East German women seeking alternative lives. But what of Strubel's East German men? In what follows I discuss male characters from the works Kältere Schichten der Luft and Vom Dorf. In both texts, an East German man is depicted as a victim of the 'Wende', even driven mad by it. East German masculinity is portrayed as both fragile and menacing. The men in question are set alongside the figure of a young, queer woman, an Antje

\footnotetext{
${ }^{28}$ Strubel, Tupolew 134, pp. 174-5.

${ }^{29}$ Ahmed describes becoming a lesbian as involving a departure from 'well trodden paths'. She goes on: 'It is interesting to note that in landscape architecture they use the term "desire lines" to describe unofficial paths, those marks left on the ground that show everyday comings and goings, where people deviate from the paths they are supposed to follow' (Queer Phenomenology, pp. 19-20).

${ }^{30}$ Ahmed, Queer Phenomenology, p. 105.

(c) The author 2009. Journal compilation (c) Blackwell Publishing Ltd. 2009
} 
Strubel-like figure. The latter represents a set of transformative possibilities, a productive nomadism, which is denied to the men themselves. Femininity, it appears here, is more resilient than masculinity, more capable of change. Such a view stands in contrast to the claim that women, more then men, have suffered as a result of the 'Wende'. ${ }^{31}$ Age is also shown as a significant factor, as older men are portrayed as struggling to adapt to new circumstances.

Kältere Schichten der Luft concerns Anja, a thirty-year-old woman from the former GDR working at a canoe camp for young people in Sweden one summer. She is approached one day by a mysterious woman, Siri, who appears to mistake Anja for her (male) lover. ${ }^{32}$ Anja and Siri, who is also German, begin a relationship. The tone of the passages evoking their interactions is surreal, dream-like. Gender is often uncertain or ambivalent here; Anja takes on the persona of a boy, referred to as 'der Junge' (e.g. $K S L$, p. 124). These dreamy passages are interspersed with more prosaic accounts of life at the camp. Most of the workers at the camp are there because of the 'Wende'; Sabine, for example, has lost her job, which is now being carried out by a machine (KSL, p. 26) - a detail that hints at the loss of various kinds experienced by many East Germans following unification, and calling to mind Maaz's designation of GDR citizens as 'das gestürzte Volk'. ${ }^{33}$

For Ralf, another of Anja's co-workers at the camp, the 'Wende' has meant the dissolution of his family and his career. Ralf has not seen his daughter for many years (KSL, p. 37). Anja happens upon a composition by her. According to this text, Ralf was in the army but was made redundant in November 1990; he later reveals to Anja that he was a border-guard: a highly symbolic occupation (KSL, pp. 37, 149). Since then, Ralf has had illpaid, temporary jobs. According to his daughter, Ralf's wife left him 'wegen der größerern Auswahl im Westen'. She adds: 'ich bin etwas, das enstand in der DDR, sagt mein Vati, in seiner sozialistischen Heimat' (KSL, p. 38). Ralf's response to his unfortunate situation is, then, to look back to the past with melancholy nostalgia.

Ralf's attempt to rape Anja reads at first like a jealous response to Anja's relationship with Siri; but it also attributable in part to the losses Ralf has experienced (KSL, p. 68). One character indeed blames Ralf's 'Verkrampfung' following the 'Wende' for the assault; it had nothing to do with Anja, she claims ( $K S L$, p. 83). While this explanation is not to be taken at facevalue, it is certainly suggested that Ralf has been severely damaged by recent political events. Anja herself cannot at first make sense of the act (KSL,

\footnotetext{
31 This is Maaz's view, for example (Das gestürzte Volk, p. 34). Compare also Braidotti's philosophical conceptualisation of the 'feminine' as 'project, as movement of destabilization of identity and hence of becoming'. Rosi Braidotti, Transpositions: On Nomadic Ethics, Cambridge 2006, pp. 183-4.

${ }^{32}$ Antje Rávic Strubel, Kältere Schichten der Luft, Frankfurt a.M. 2007, pp. 9-10. Further references to this work appear as KSL.

${ }^{33}$ Maaz, Das gestürzte Volk.
} 
p. 71), but she eventually realises that it was Ralf's unconscious homosexual desire that led him to it; Ralf had not wanted her, but the boy: 'Es war der Junge, den er anziehend fand, erregend' (KSL, p. 177). When Ralf again approaches Anja in a sexually aggressive fashion, she pushes him away; he falls and dies (KSL, pp. 176-7).

This text too presents a queer challenge to gender boundaries alongside a probing of East German identity. Ralf, interestingly, aligns himself with Anja, claiming that they are both '[a]m Rand' (KSL, p. 148). This putative alliance is uneasy and unsuccessful, but there is a suggestive linkage of concerns here, as the marginal East German male seeks support from the queer woman. It is indeed suggested that both queers and East Germans are 'am Rand'. Homophobia is alluded to when a football is found in the camp with the slogan 'No gays!' written upon it (KSL, p. 64). It is also implied that the situation of East Germans is habitually trivialised; 'die ostdeutsche Lage' is talked of over coffee, alongside the latest films (KSL, p. 27). The workers in the camp are as mentioned 'refugees' from post-'Wende' Germany, having no secure place in society.

One could read the demise of Ralf as symbolic of the need to move on from, or 'kill', the 'Resignation, Depressivität, Larmoyanz, Gereiztheit und Gewalt' identified by Maaz in his fellow East Germans, and of the beginning of a new kind of (East) Germanness, embodied by Anja. Anja is not necessarily rooted in Germany, however. While Anja anticipates returning to her home country, we do not see this occur, and what is finally asserted is '[der] Wunsch, sich aufzulösen, hinein in die kälteren Schichten der Luft' (KSL, p. 189). The dissolution of (national) identity is presented as desirable, then, rather than its resumption. Perhaps, like Christiane, Anja will fail to return to Germany; or perhaps, like Strubel herself, she will return only on a conditional, partial basis. I will discuss Strubel's own positioning in more detail shortly.

Vom Dorf also features a man disturbed by the disappearance of his country. This playful and self-conscious work takes the form a series of short texts allegedly written by someone passing himself off as 'Antje Rávic Strubel'. According to the preface written by Strubel, who claims to be acting here as editor, this man sent his manuscript anonymously to her publisher. ${ }^{34}$ The manuscript was in two parts: firstly, there was a collection of 'Weihnachtsgeschichten', ostensibly written by Strubel: 'Der anonyme Absender hatte die Geschichten nicht nur unter meinem Namen verfaßt. Er hatte außerdem versucht, meinen Stil nachzuahmen' ( $V D$, p. 8). Secondly, there were a series of diary entries, headed 'Protokolle'. In these texts, the author of the stories reveals his obsession with Strubel and his plan to imitate her.

In the preface, Strubel describes a man in his late fifties whom she remembers from many of her readings ( $V D$, p. 8$)$. She attempts to track him

\footnotetext{
${ }^{34}$ Antje Rávic Strubel, Vom Dorf. Abenteuergeschichten zum Fest, Munich 2007, p. 7. Further references to this work appear as $V D$.
} 
down but fails, and concludes that no further investigations are required ( $V D$, p. 10). The issues of identity, authorship, and authenticity are playfully dealt with. Strubel the editor claims: 'Den Versuch, meinen Stil täuschend echt nachzuahmen, halte ich für mißglückt. Aus diesem Grund ist es mir am Ende nicht ganz so schwer gefallen, mich zu einer Herausgabe dieser Fälschungen zu entschließen' ( $V D$, p. 10). The 'falseness' of the voice is what allows the author to publish this book. What follows, then, is ostensibly a bad imitation of Strubel. And yet paradoxically this book is more 'honest' than many, according to Strubel; she claims that many contemporary literary works steal sections from other novels, or imitate other novels shamelessly, whereas in this book, the deception is made clear from the outset by the inclusion of the fraudster's 'Protokolle' (VD, p. 11).

What does all this trickery imply about East German identity? On one level, it appears in this text to be shaky and disturbed. Like Ralf, Strubel's stalker/imitator has suffered in the wake of the 'Wende', a period he concedes was 'etwas schwierig' for him ( $V D$, p. 75). As a young man, he was energetic and confident. He spent time in Moscow and studied Economics, after which he gained a good job as an 'Ingenieur-Ökonom'. The 'Wende' caused a crisis, as the man was forced to acknowledge that he was no longer an ambitious youth: 'Im Spiegel war ich alt' ( $V D$, p. 76). This loss of certainty and confidence recalls Maaz, who asserted in 1991: 'ich stecke mitten in einem Verlust-Syndrom' and 'die alte Ost-Identität stimmt nicht mehr'. ${ }^{35}$ The stalker describes his current job in a 'Ministerium'; he works there not out of choice, but because it offers a 'Notlösung'. He sits idly in an office, where nothing is expected of him, and waits for retirement, six years away ( VD, pp. 51-2). He claims that there are others like him:

Viele derjenigen, die ich von früher kenne und die mit mir aus den unterschiedlichsten Berufen, für die es heute keine Verwendung mehr gibt, hierher gewechselt sind, haben eine ähnliche Einstellung. Sie warten. Sie bleiben im Hintergrund. Sie alle teilen dieses Gefühl, am Rand zu stehen. (VD, p. 52)

The older, East German male is again depicted as redundant, forced into a humiliating passivity. Like Ralf, he is 'am Rand'.

And like Ralf, he becomes interested in a young woman, here 'Antje Strubel', whom he hears speak in a bookshop. He is particularly struck by a statement Strubel makes at the reading. Alluding to the disappearance of the GDR, Strubel claims that such changes can pose productive challenges: 'Für sie sei das Verschwinden all der Verhaltensregeln, Glaubenssätze [...] geradezu eine Aufforderung, sich zu ändern, vielleicht sogar, sich neu zu erfinden' ( $V D$, p. 43). This assertion is reminiscent of Maaz's reflection that 'Meine bisherige Anpassung ergibt keinen Sinn mehr, darin liegt eine

${ }^{35}$ Maaz, Das gestürzte Volk, pp. 10 and 18. 
große Chance für weitere Entwicklungen. ${ }^{36}$ Strubel's words captivate the stalker and trigger his obsession with her. But instead of reinventing himself, he succeeds only in mimicking another. He realises 'wie wenig stabil die eigene Person ist', and reflects on the changeable nature of virtual identities (VD, pp. 137, 102); for him, however, such lack of stability does not spell liberating transformation, but madness.

Like Ralf, the stalker sees in Anja/Antje a companion in otherness. At the reading, Strubel claims to be a 'Fremde des menschlichen Herzens', an assertion that prompts in the stalker the following reflection: 'Wenn sie nur auch wüßte, daß man selbst so ein Fremder ist -' ( $V D$, p. 50). He views himself and Strubel as sharing a 'Geistesverwandtschaft', and claims to be glad she is not sexually interested in men, as an erotic attachment would only interfere with their spiritual connection ( $V D$, p. 143). But his beliefs are clearly delusional, and his eventual disappearance suggests that like Ralf, this man has no home, no place in the world.

East German masculinity appears anxious, then. But the fictional Strubel is depicted as mobile and active. In one story, she sprouts wings ( $V D$, pp. 1526). Elsewhere, she and her friend are magically transported to the American desert ( $V D$, p. 108). Moreover, the text's games with authorship and authenticity themselves hint at a robust and self-aware authorial sensibility and suggest confidence; perhaps East Germans are no longer necessarily despairing and confused, and humour and inventiveness can now flourish.

In both of these texts, then, the East German male is disturbed, and seeks release or refuge in Strubel, or a Strubel-like figure, whom he stalks, imitates, even attempts to rape. Ultimately, he dies or disappears. The queer, East German female subject remains alive, but her position in the Berlin Republic is not necessarily certain or comfortable. This lack of comfort will be explored more now.

\section{SWEDEN: AN ALTERNATIVE 'HEIMAT’?}

In Kältere Schichten, Anja leaves behind '[die] Doppelhaushälften und eine[] Antragsbürokratie, in der immer jemand fragte, was ich machte und wer ich war' (KSL, p. 22) ${ }^{37}$ Antje does the same in the non-fiction Gebrauchsanweisung für Schweden, a guidebook-cum-memoir recording Strubel's experiences in that country. As we will see, the text posits a specifically East German form of nomadism. It also poses a number of challenges to today's Berlin Republic. In particular, Strubel's queer gaze alights critically on the German construction of gender and the family.

In her introduction to the book, Strubel describes the 'Sehnsucht' that she experienced as a child in the GDR, watching the ferries leave for

\footnotetext{
${ }^{36}$ Ibid., p. 19. Maaz also notes here the dangers of lapsing into a new kind of 'Anpassung'.

${ }^{37}$ Strubel stated publicly at a reading in Berlin on 27 June 2008 that she herself wishes to escape this kind of invasive bureaucracy.
} 
Sweden. This yearning has left its mark on her: 'Noch immer entzündet jede Fähre die Sehnsucht in mir erneut, und seit die Grenzen offen sind, bin ich häufig an Bord gegangen. ${ }^{38}$ Indeed, Strubel suggests that East Germans in general are characterised by such a tendency towards imaginative yearning: "Vielleicht ist für Ostdeutsche der Boden der Realität immer noch dünner, vielleicht ist man geübter darin, in Welten der Vorstellung, in Sehnsuchtsgebiete abzutreiben' ( $G, \mathrm{p} .122)$. This is a suggestive speculation; it implies that the East German sensibility might be inherently flexible and creative ('nomadic'). At the same time, Strubel suggests again the difficulties involved in being East German; she is at one point reminded of 'jene Ostdeutschen [...], die nach der Wende das Versäumte so sehr aufzuholen suchten, dass ihr Eifer, westlicher zu sein als jeder Westler, sie eigentlich erst als Ostdeutsche entlarvte' ( $G$, p. 76) - an observation that is both humorous and poignant, recalling the insecure male characters of Strubel's fictions, and Maaz's downbeat meditations on his unstable self-identity. There is thus a tension to be detected: between a view of post-unification East German subjectivity as 'nomadic', and a recognition of the widespread difficulties involved in being East German, particularly for those of Strubel's parents' generation.

Strubel reports that the nature of her yearning has changed since the 'Wende'. While at first she experienced a childlike lust for adventure, a shift occurred: 'Und später hatte ich genug Westen im Kopf, im Blut und im Portemonnaie, um mich wieder nach einer besseren Welt zu sehnen' ( $G$, p. 10). Thus, the excitement brought about by unification gave way to a more sober, critical approach to the Berlin Republic. In Strubel's case, this disillusionment did not result in mournfulness or nostalgia, but rather in movement and a desire for change. There is no 'Ostalgie' here. The GDR regime is satirised, in particular with regard to its restriction of citizens' movement; the Stasi '[wollte] ihre Staatsbürger so sehr vor dem Westen schützen [...], dass sie sie lieber ins Gefängnis steckte, als ihnen auch nur einen Blick ins Auge des Feindes zu gestatten' ( $G$, p. 35). Elsewhere, when Strubel learns about the prominence of 'Arbeiterliteratur' in Sweden, she notes wryly: 'Arbeiterliteratur hat für mich immer einen bitteren Beigeschmack' ( $G$, p. 159).

Strubel does not seek to escape into the past, then, although perhaps she does seek to 'escape' to Sweden. Strubel admires in Swedes their pragmatism and anti-materialism, the simple solitude that is possible in Sweden, and the lack of hierarchy - all of which compares favourably with Germany $(G$, pp. 58, 94, 163). Strubel also writes approvingly about the Swedish model of parenting, claiming that Swedish men are often active parents. German fathers, in contrast, have no positive role models ( $G$, p. 188). Strubel's critical take on gender is apparent when she observes the 'steinzeitliche Muster' that underlie the views of gender held by groups

${ }^{38}$ Strubel, Gebrauchsanweisung, p. 9. Further references to this work appear as $G$. 
of canoeists on holiday in Sweden ( $G$, p. 136). Strubel also compares the roles of the individual, the family, and the state in Germany and Sweden. While the Swedish state is answerable to and responsible for the individual, Strubel claims, the German family and state are intertwined and interdependent institutions. This means that in Germany, queer families are perceived as threatening: 'Die Ehe [in Germany] ist nach wie vor als Feste des Staates heilig; Regenbogenfamilien dagegen stellen als frei gewählte Form des Zusammenlebens eine Gefährdung dieser Allianz dar' (G, p. 191).

As implied earlier, 'nation' and 'gender' are linked constructs; seen in this light, Strubel's dual challenge to heterosexism and nationalism is logical. Regarding this issue of nationalism, Strubel reflects that Germany is subject to '[die] einfache[] Verlockung von nationaler Macht, Herrschaft und Gefolgstreue' ( $G$, p. 195). And yet Germany is 'verkrampft' in relation to itself as a nation, unlike Sweden, where a casual, benign form of nationalism is in evidence ( $G$, p. 205). Thus, as Brockmann also suggests, the nation is not to be discarded - but it does need to be re-imagined.

\section{CONCLUSION}

Strubel's work offers a significant and enriching contribution to debates concerning post-unification East German identity and culture. Strubel's (partial) departure from Germany - both 'actual' and literary - is a powerful gesture that serves to highlight ruptures and problems within the Berlin Republic. The fact that Strubel has translated from English underscores her position as an insider who is also (sometimes) outside. Strubel is an East German who is also a German and a nomad. As such, she challenges rigid national boundaries, and restrictive forms of nationalism. She also challenges the erasure of the East German experience. Maaz claims: 'Gemäß dem dualistischen Entweder-Oder-Verständnis der abendländischen Kultur müssen die Menschen in der ehemaligen DDR alles vergessen und aufgeben, was ihr bisheriges Leben bestimmt hat. ${ }^{39}$ This dualistic thinking is damaging, he asserts. Like Cooke, Maaz implies that remembering is healthy and necessary, and that such oppositions as East/West, self/other, and past/present should not be rigidly enforced. I would suggest that male/female is another binary that can and should be challenged, so that new understandings of (German) identity can emerge. Strubel's refusal to toe the line is thus instructive and important.

\footnotetext{
${ }^{39}$ Maaz, Das gestürzte Volk, p. 159. 